\title{
Action of Thyroid Hormones, T3 and T2, on Hepatic Fatty Acids: Differences in Metabolic Effects and Molecular Mechanisms
}

\author{
Fabrizio Damiano ${ }^{1, *}$, Alessio Rochira ${ }^{1}$, Antonio Gnoni ${ }^{2}$ and Luisa Siculella ${ }^{1}$ \\ 1 Laboratory of Biochemistry and Molecular Biology, Department of Biological and Environmental Sciences \\ and Technologies, University of Salento, 73100 Lecce, Italy; alessio.rochira@unisalento.it (A.R.); \\ luisa.siculella@unisalento.it (L.S.) \\ 2 Department of Basic Medical Sciences, Section of Medical Biochemistry, University of Bari Aldo Moro, \\ 70125 Bari, Italy; Antonio.gnoni@uniba.it \\ * Correspondence: fabrizio.damiano@unisalento.it; Tel.: +39-0832-298698
}

Academic Editor: Johannes Haybaeck

Received: 11 February 2017; Accepted: 27 March 2017; Published: 31 March 2017

\begin{abstract}
The thyroid hormones (THs) 3,3',5,5'-tetraiodo-L-thyronine (T4) and 3,5,3'-triiodoL-thyronine (T3) influence many metabolic pathways. The major physiological function of THs is to sustain basal energy expenditure, by acting primarily on carbohydrate and lipid catabolism. Beyond the mobilization and degradation of lipids, at the hepatic level THs stimulate the de novo fatty acid synthesis (de novo lipogenesis, DNL), through both the modulation of gene expression and the rapid activation of cell signalling pathways. 3,5-Diiodo-L-thyronine (T2), previously considered only a T3 catabolite, has been shown to mimic some of T3 effects on lipid catabolism. However, T2 action is more rapid than that of T3, and seems to be independent of protein synthesis. An inhibitory effect on DNL has been documented for T2. Here, we give an overview of the mechanisms of THs action on liver fatty acid metabolism, focusing on the different effects exerted by T2 and T3 on the regulation of the DNL. The inhibitory action on DNL exerted by T2 makes this compound a potential and attractive drug for the treatment of some metabolic diseases and cancer.
\end{abstract}

Keywords: 3,5-diiodo-L-thyronine; 3,5,3'-triiodo-L-thyronine; acetyl-CoA carboxylase; citrate carrier; de novo lipogenesis; fatty acid synthase; lipid lowering action

\section{Introduction}

Thyroid hormones (THs) are represented by 3,3',5,5'-tetraiodo-L-thyronine (or thyroxine, T4) and 3,5,3'-triiodo-L-thyronine (T3). Thyroid gland produces mainly T4, whereas the bulk of the systemic T3, which is considered the most potent thyroid hormone, is generated by the deiodination of T4 in peripheral tissues. Three types of deiodinases exist: the type I (D1) is present in peripheral tissues, including liver; the type II (D2) is mainly expressed in the pituitary gland, brain, and brown adipose tissue; and the type III (D3) is present in placenta, brain, and skin [1]. It is generally accepted that D1 and D2 contribute to the conversion of most of T4 into T3.

In the blood, THs are mainly bound to specific proteins, which transport them through the circulation; only a small part of THs is free and exerts its action on target tissues. THs have profound effects on many physiological processes, such as development, growth and metabolism; defects in their production are not compatible with health. THs control the metabolism of proteins, carbohydrates and lipids. Increased levels of THs stimulate fat mobilization from adipose tissue, leading to raised concentrations of free fatty acids in the plasma. THs also enhance oxidation of fatty acids in many tissues, and affect cholesterol metabolism as well [2]. T3 and some THs mimetic compounds reduce 
the plasma concentration of cholesterol, by inducing its hepatic uptake and conversion into bile acids and by favouring faecal bile acid excretion [3,4]. In liver, gluconeogenesis and glycogenolysis are promoted by THs in order to generate free glucose $[5,6]$, whereas in peripheral tissues THs stimulate the insulin-dependent uptake of glucose into cells and the subsequent glycolysis [5,7]. THs enhance the synthesis as well as the degradation of proteins. Supraphysiological doses of THs cause the depletion of skeletal muscle protein stores and increase the activities of protein catabolizing lysosomal enzymes [8].

THs control the energy metabolism and mitochondria are considered possible subcellular loci of thyroid hormone action [9]. In the mitochondrion, the major site of oxidative processes, THs stimulate the oxygen consumption as well as the ATP hydrolysis [7], thus participating to the regulation of the basal metabolic rate (BMR) and to the body heat production. Extensive changes occur in the mitochondrial compartment in response to the thyroid state of the animal $[9,10]$.

T3 can be further deiodinated to 3,5-diiodo-L-thyronine (T2). Several studies indicated that, in addition to T3, T2 exhibits important biological effects in liver as well as in other tissues (for a review see [11]). A great body of evidence has reported that T2, previously considered only a T3 catabolite, is able to mimic some of T3's effects on the metabolism [11]. T2 action appears to be more rapid than that of T3, and seems to be independent of protein synthesis [11-15]. It has been shown that $\mathrm{T} 2$ administration to rats increases their resting metabolic rate by modulating mitochondrial function [16-18], prevents diet-induced obesity by enhancing burning of fats [19], and reduces liver steatosis in rats fed on a high-fat diet [20]. T2 is also able to reduce the fat storage excess by acting directly on liver cells [21]. Lanni and colleagues [19] reported that action of T2 occurs without unfavourable side effects (i.e., thyrotoxicosis) usually observed when T3 or T4 is administered to rats [22].

Moreover, $\mathrm{T} 2$ is able to influence mitochondrial activities. It stimulates the mitochondrial oxidative capacity and respiration rate $[9,11,14,15,23]$ and increases FoF1-ATP synthase expression and activity in rat liver mitochondria [14,24].

\section{Genomic and Nongenomic Mechanisms of Action of Thyroid Hormones}

THs play fundamental roles in the regulation of cell functions through genomic and nongenomic actions.

\subsection{Genomic Actions}

The classic, genomic mechanism of THs action requires the involvement of nuclear thyroid receptors (TRs), bound to the promoter of target genes. TRs are DNA-binding proteins that function as hormone-responsive transcription factors with a mechanism similar to that of receptors for steroid hormones [25]. Thyroid hormone receptor- $\alpha 1$ (TR $\alpha 1)$ and thyroid hormone receptor- $\beta 1$ (TR $\beta 1$ )/thyroid hormone receptor- $\beta 2$ (TR $\beta 2$ ) are encoded by Thra and Thrb genes, respectively. Each TR forms a heterodimer with RXR, or a homodimer with another thyroid receptor, which binds to DNA in a T3-independent way [25]. In vitro experiments suggest that the binding of TRs could occur on responsive elements constituted by doublets of the half-site AGGCTA, or by DNA elements bearing variations in sequence, spacing and orientation of this half site [26]. T3 and T4 enter cells through several membrane transporter proteins, some of them require ATP hydrolysis for the transport activity [27]. Once inside the nucleus, THs interact with the receptor bound to the promoter of the target genes, modulating their expression, either by stimulating or by inhibiting transcription [25].

\subsection{Nongenomic Actions}

Beyond the genomic effects, THs have been shown to initiate non-genomic signalling, which has been described at plasma membrane level, in cytoskeleton, in cytoplasm [28-30] and in various organelles, such as mitochondria [20]. These signals include alterations in transport of $\mathrm{Ca}^{2+}, \mathrm{Na}^{+}$ 
and glucose, as well as changes in activities of several kinases such as protein kinase C (PKC), phosphoinositide 3-kinase (PI3K), and mitogen-activated protein kinase (MAPK) [29,30].

The non-genomic actions of THs require a plasma membrane receptor or thyroid receptors located in cytoplasm [29]. The plasma membrane receptor is located on the integrin $\alpha \mathrm{vb3}$ at the Arg-Gly-Asp recognition site, important for the binding of extracellular matrix proteins [31-33]. Acting at the integrin receptor and without cell entry, T4 can foster ERK1/2-dependent serine phosphorylation of TR $\beta 1$, activating it [34]. In rat skeletal muscle T3 rapidly activates the protein kinase B (PKB)/Akt pathway, resulting in the stimulation of both fatty acid and glucose metabolism [35].

In human fibroblasts the PKB/Akt pathway is implicated in the transduction of the thyroid hormone signal, culminating in the activation of specific transcription factors [36]. It has been reported that the PKB/Akt transduction pathway requires the functional interaction between cytoplasmic TR $\beta 1$ and PI3K. This interaction causes the activation of PKB/Akt, which in turn induces the mTOR pathway implicated in the stimulation of protein synthesis [36]. Finally, T3 induces PKC activation in human hepatoma cells [29], in rat liver slices and in isolated hepatocytes [37].

\section{Fatty Acid Metabolism in Liver}

Metabolism of fatty acids (FA) is largely recognised as a target of THs action. Liver plays a crucial role in regulating fatty acid metabolism either in catabolic and anabolic direction. In liver free FA can have different sources:

(i) can be synthesized directly within the hepatocytes through the involvement of de novo lipogenesis (DNL),

(ii) can be taken up by liver from the pool of plasma FA released by the adipose tissue,

(iii) can be generated in liver from the hydrolysis of chylomicrons coming from intestine.

The metabolic fate of FA in liver is regulated by the nutritional/hormonal status of the organism: when energy request is low, hepatic FA are esterified into glycerol and stored as triacylglycerols (TAGs) or secreted in the plasma as very low density lipoprotein (VLDL). Vice versa, when energy request occurs, FA are oxidized mainly at mitochondrial level through the $\beta$-oxidation pathway. Liver mitochondria play a strategic role both in fatty acid $\beta$-oxidation, the major process by which FA can generate energy, as well as in DNL.

\section{Mitochondrial Fatty Acid $\beta$-Oxidation}

Fatty acid $\beta$-oxidation is localized in the mitochondrial matrix, while FA come from the cytosol. Short- and medium-chain FA freely enter mitochondria, while long-chain FA are preliminarily activated to acyl-coenzyme A by long chain acyl-CoA synthase, present in the outer mitochondrial membrane. Due to the impermeability of the inner mitochondrial membrane (IMM) to electrically charged molecules, the transfer of acyl-CoA across this membrane occurs through three consecutive steps: (1) the transfer of acyl group from acyl-CoA to carnitine, producing acylcarnitine, catalysed by carnitine palmitoyltransferase I (CPT I) at the external side of IMM; (2) the transport of acylcarnitine through the IMM by the carrier protein carnitine-acylcarnitine translocase; (3) the intramitochondrial reconversion of acylcarnitine to acyl-CoA ester by carnitine palmitoyltransferase II (CPT II). After that fatty acid $\beta$-oxidation may occur.

The main control of the rate of mitochondrial $\beta$-oxidation flux resides at the level of CPT I [38]. The major physiological inhibitor of CPT I is malonyl-CoA, the product of acetyl-CoA carboxylase, which catalyses the initial step of DNL.

Once in the mitochondrial matrix, the fatty acid $\beta$-oxidation process occurs through four individual reactions generating reducing equivalents in the form of $\mathrm{FADH}_{2}$ and $\mathrm{NADH}+\mathrm{H}^{+}$, which are reoxidized to FAD and $\mathrm{NAD}^{+}$by the mitochondrial respiratory chain, with the simultaneous production of ATP by the oxidative phosphorylation system. 
The complete oxidation of acyl-CoA occurs through several cycles, shortening fatty acid of two carbons (i.e., acetyl-CoA) at each cycle. The end product acetyl-CoA is further metabolized in the tricarboxylic acid (TCA) cycle.

\section{De Novo Lipogenesis (DNL) and Its Regulation}

In this review we focused on THs effects on the DNL in liver. DNL is the metabolic pathway by which FA, primarily palmitic acid, are synthesized mainly from carbohydrates. The flow of carbons from glucose to fatty acids in the lipogenic pathway involves a coordinated series of enzymatic reactions. Glucose, taken up by the glucose transporter, enters the glycolytic pathway in the cytosol and generates pyruvate (Figure 1). Through mitochondrial pyruvate carrier (MPC), the pyruvate enters the mitochondrion [39], where, by the action of pyruvate dehydrogenase, it is converted into acetyl-CoA, which condenses with oxaloacetate to form citrate in the TCA cycle. When cellular energy is in excess, TCA cycle is inhibited, and the produced citrate exits the mitochondrion through the citrate carrier ( $\mathrm{CiC})$, localized in the IMM [40-42]. Once in the cytosol, by the action of ATP citrate lyase (ACLY), citrate is reconverted in oxalacetate (OAA) and acetyl-CoA, which represents the primer for DNL.
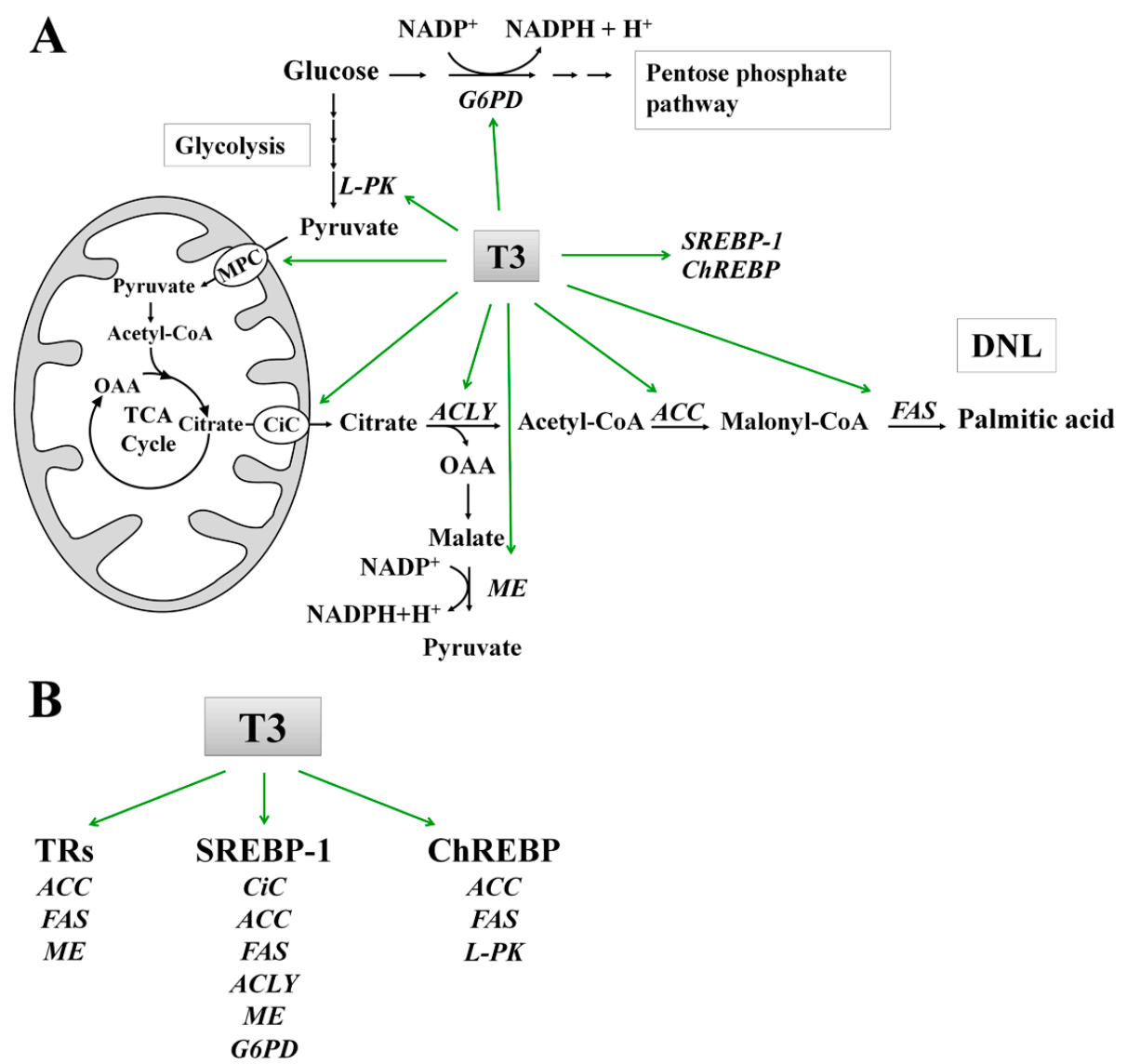

Figure 1. (A) Schematic representation of the role of T3 in the stimulation of activity and expression of enzymes, mitochondrial carriers, and transcription factors involved in the synthesis of palmitic acid from glucose; and (B) Effects of T3 on the activation of fatty acid synthesis through thyroid receptors (TRs) and lipogenic transcription factors (SREBP-1 and ChREBP). Abbreviations: ACC, Acetyl-CoA carboxylase; ACLY, ATP-citrate lyase; ChREBP, Carbohydrate Response Element Binding Protein; CiC, Citrate carrier; DNL, De novo lipogenesis; FAS, Fatty acid synthase; G6PD, Glucose-6-phosphate dehydrogenase; L-PK, Liver pyruvate kinase; MPC, Mitochondrial pyruvate carrier; ME, Malic enzyme; OAA; oxalacetic acid; SREBP-1, Sterol regulatory element-binding protein 1; TCA, Tricarboxylic acid cycle. 
DNL is a cytosolic process catalysed by two multimeric enzymes working in sequence: (i) acetyl-CoA carboxylase (ACC) and (ii) the multienzymatic system of fatty acid synthase (FAS).

ACC catalyses the carboxylation, biotin dependent, of acetyl-CoA to form malonyl-CoA, which elongates the acyl chain by two carbons at a time, by a series of reactions catalysed by FAS. Palmitic acid (C16:0) is the main end product of this pathway. Palmitate can be further converted into longer and unsaturated fatty acids by fatty acid chain elongation and desaturation processes.

\section{Regulation of Enzyme Activities of DNL}

ACC is considered a key enzyme of DNL [43]. Its activity is inhibited by long chain acyl-CoAs, while it is positively modulated by citrate, which, as above reported, is exported from mitochondria by CiC. ACC gene transcription is under the control of multiple promoters, which are regulated by diet and hormones. The expression and the activity of ACC are reduced by starvation and glucagon whereas they are induced by insulin and fat-free diet rich in carbohydrates [44].

FAS is primarily expressed in the cytosol of liver, brain, adipose tissue, lung, and lactating mammary gland cells, where DNL is an important process. In mice or rats re-fed on a high-carbohydrate diet a robust induction of FAS expression, mediated by both insulin and glucose, was observed [45]. Conversely, glucagon and cyclic AMP inhibit the increase of FAS expression induced by carbohydrate re-feeding. Polyunsaturated fatty acids also exert a strong inhibition of FAS expression [45] and activity [46].

$\mathrm{CiC}$ plays an important role in the intermediary metabolism $[41,42,46,47]$ and its activity is modulated by nutritional factors [46,48-51], and hormonal factors [52]. Moreover, the expression and the activity of $\mathrm{CiC}$ is affected by different pathological states [53-56].

Noteworthy, a covariance in the activities of CiC, ACC and FAS has been reported in different nutritional and hormonal states, thus highlighting a close correlation between mitochondrial (CiC) and cytosolic (ACC and FAS) reactions in FA biosynthesis $[46,48,49]$. In addition, high level of malonyl-CoA, the product of ACC, inhibits CPT I activity and decreases fatty acid $\beta$-oxidation; thereby, through malonyl-CoA, a coordination among hepatic FA synthesis, FA $\beta$-oxidation and ketogenesis occurs [43]. The hepatic neo-synthesized FA represent an important source for TAGs synthesis and hence for secretion rate of hepatic VLDL. Thus, hepatic DNL is closely correlated with plasma lipid concentration [57].

At transcriptional level, lipid synthesis is regulated by sterol regulatory element-binding proteins (SREBPs) [58] and carbohydrate response element binding protein (ChREBP) [59], which are considered the most important lipogenic transcription factors. SREBPs belong to a family of transcription factors including SREBP-1a, SREBP-1c and SREBP-2 that are involved in the control of lipid homeostasis through the regulation of several genes [58]. SREBPs are synthesized as inactive precursors (pSREBPs) bound to the endoplasmic reticulum (ER), where their regulatory domain interacts with SREBP-cleavage-activating protein (SCAP). SCAP functions as a sensor of membrane cholesterol levels. When an activation signal occurs, the SREBP-SCAP complex translocates from the ER to the Golgi apparatus, where a two-step proteolytic cleavage releases the N-terminal half of SREBPs (nSREBPs), allowing its entry into the nucleus. Conversely, in the absence of stimuli, the SREBP-SCAP complex remains in the ER membrane owing to its interaction with the ER-embedded insulin-induced gene (INSIG) protein [60].

ChREBP is a glucose-sensitive transcription factor controlling the conversion of carbohydrates into lipids in the liver [59]. ChREBP is a bZIP transcription factor that forms a heterodimeric complex with another bZIP protein max-like protein X (MLX) [59]. In low-glucose conditions, ChREBP is located in the cytosol and enters into the nucleus under high-glucose conditions [61]. 


\section{Molecular Mechanisms of T3 Action on DNL}

\subsection{Effect of T3 on the Lipogenic Enzymes: ACC and FAS}

DNL pathway is under the control of T3 [62] (Table 1). Within $4 \mathrm{~h}$ following the addition of T3 to monolayer cultures of hepatocytes isolated from eu- and hypothyroid rats, a very distinct stimulation of fatty acid synthesis and of FA incorporation into lipid fractions is observed [62]. However, stimulation of DNL by T3 is attenuated in rats fed high glucose diet supplemented with fats from beef tallow or safflower oil [63].

Different steps of DNL are increased in response to T3 administration [64]. T3 can modulate the expression of its target genes through two different ways: (i) directly, by the activation of thyroid receptor that interacts with the T3 responsive element (TRE) in the promoter region of the target genes [65-67]; (ii) indirectly, by activating transcription factors which in turn regulate the expression of target genes [68].

T3 is able to affect directly the two lipogenic enzymes ACC and FAS (Figure 1). T3 up-regulates ACC expression in chow-fed rats [69] through the TR bound to promoter of ACC gene [65,70]. In isolated chicken embryo hepatocytes, treatment with T3 increases the FAS mRNA [71]. In human hepatocarcinoma HepG2 cells, T3 activates FAS mRNA transcription through a TRE located in the FAS promoter [28]. A TR/RXR heterodimer binds the TRE even in the absence of the hormone, but the efficiency and the stability of this binding is increased in response to T3 [28]. T3 may also stimulate the expression of ACC and FAS via the transcription factor SREBP-1 [72]. Indeed, T3 up-regulates hepatic SREBP-1 [68] (Figure 1), which in turn stimulates the expression of ACC and FAS genes [73], through two adjacent SREBP-1 binding sites in their promoter. The expression of SREBP-1c is negatively regulated by T3 in chow-fed mice [74]. Experiments performed in vivo demonstrated that, when compared to control rats, SREBP-1 mRNA abundance was reduced in liver from T3-treated rats $[30,75]$. By contrast SREBP-1 protein amount was increased in hyperthyroid rats [30]. The molecular mechanism underlying the opposite effect of T3 on SREBP-1 mRNA versus the SREBP-1 protein in rat liver has not yet been investigated [30].

Recently, it has been evidenced in HepG2 that T3 is able to raise SREBP-1 protein level without affecting its mRNA level, enhancing the translation efficiency of its mRNA by an internal ribosome entry site (IRES)-mediated mechanism [30]. This effect is due to the non-genomic activation of both MAPK/ERK and PI3K/Akt pathways [30]. The administration of non-specific protein kinase inhibitors to cultured hepatocytes from embryonic chicken abolished T3-induced increase of the activity and expression of lipogenic enzymes FAS and ACC [76], showing a T3 action on signalling pathways.

$A C C$ and FAS genes are positively regulated by ChREBP in response to glucose [59] (Figure 1). It is well demonstrated that in chow-fed mice T3 is able to activate ChREBP in liver (Figure 1) [77,78], suggesting the involvement of this transcription factor in the control of lipogenesis by THs.

\subsection{Role of $\mathrm{T} 3$ in the Conversion of Carbohydrates into Fatty Acids}

Two mitochondrial carrier proteins, modulated by T3, are involved in the conversion of carbohydrates into fatty acids: the mitochondrial carrier for pyruvate (MPC) and that for citrate (CiC) (Figure 1). The activity of MPC is enhanced in chow-fed hyperthyroid rats [79]. When compared to chow-fed euthyroid rats, $\mathrm{CiC}$ activity is severely down regulated in hypothyroid [53,54], and up regulated in hyperthyroid rats [80]. It has been demonstrated that hypothyroidism negatively affects the $\mathrm{CiC}$ expression at both transcriptional and post-transcriptional levels, through the inhibition of transcriptional rate of $\mathrm{CiC} \mathrm{mRNA}$ and of its splicing [54].

T3 regulates the expression of some genes implicated in the glucose catabolism, in order to promote the production of acetyl-CoA and NADPH required for DNL (Figure 1). These genes include liver pyruvate kinase $(L-P K)$ [81], ACLY [82], malic enzyme $(M E)$ [83,84] and glucose 6-phosphate dehydrogenase $(G 6 P D)$ [85]. 
In starved and high carbohydrate-refed rats, thyroid ablation did not alter the transcription of the gene for L-PK but caused a decrement in the L-PK mRNA content [81]. This suggests that T3 positively regulates L-PK expression at a post-transcriptional level [81]. However, L-PK is a well-known target of ChREBP, and a carbohydrate responsive element has been found in its promoter [86]. Thus, T3 may indirectly stimulate the L-PK expression through the activation of ChREBP [77]. In the vascular smooth muscle cell line, T3 controls the quaternary structure of the M2 isoform of PK (PKM2).

T3 reversibly binds to the monomeric and inactive form of PKM2, thus preventing the association of monomers to form the enzymatically active tetramer [87].

ACLY catalyses an important reaction linking glucose catabolism to DNL, by converting cytosolic citrate to oxaloacetate and acetyl-CoA, which is required for DNL and cholesterol synthesis. In cultured rat hepatocytes, T3 causes an increment of ACLY enzymatic activity [82], through stimulation of ACLY mRNA transcription [88] (Figure 1). The activation of ACLY expression by treatment with T3 is also observed during the differentiation of murine adipocytes [89]. Even though a TRE has not been found so far in the ACLY gene, T3 could induce the trans-activation of ACLY gene by SREBP-1, through a sterol regulatory element located in its promoter region [90].

ME catalyses the oxidative decarboxylation of malate to pyruvate with the concomitant production of NADPH, required for DNL (Figure 1). In hepatocytes isolated from chick embryo liver, T3 stimulates the ME activity as well as the transcription of the corresponding mRNA [76], by binding several TRE present in the $5^{\prime}$-flanking region of its gene [91]. When compared to chow-fed euthyroid rats, the level of ME mRNA was found to increase in hyperthyroid rats fed a high carbohydrate, fat-free diet [92]. The activation of ME expression by SREBP-1 has been also described [93]. T3 effects were reported for G6PD, another important NADPH producer that belongs to the pentose phosphate pathway (Figure 1). T3 is able to enhance hepatic G6PD activity in chow-fed rats [94,95], but remains unclear whether T3 directly induces G6PD gene expression [85,95]. It is well established, instead, the positive effect of SREBP-1 on the expression of G6PD [93].

There is another actor involved in the regulation of DNL by T3: Spot 14 (S14). S14 is a family of genes which encode for two proteins S14 and S14-R, regulated by thyroid hormone and implicated in the control of lipid synthesis [96,97]. S14 gene is highly regulated at the transcriptional level by SREBP-1c [98] and ChREBP [99].

Although DNL is increased in experimental models of hyperthyroidism, a reduced amount of plasma triacylglycerols and VLDL, as well as of hepatic intracellular TAGs was observed [100,101]. This can be explained, at least in part, by the increased FA oxidation observed in these models [100]. Beyond these mechanisms that counterbalance the increased hepatic TAGs synthesis, there is an extra-hepatic TH action that increases lipid clearance from the circulation, reducing serum lipid levels [90]. In hypothyroidism, however, concomitant with a reduction of FA synthesis [102] is also observed a FA oxidation decrease, which causes an increment of VLDL secretion by liver [103]. 
Table 1. Role and mechanism of action of $\mathrm{T} 3$ on activity or expression of enzymes and other proteins involved in fatty acid metabolism.

\begin{tabular}{|c|c|c|c|c|c|}
\hline Experimental Model & Time of Treatment & & Effect of T3 on Lipid Metabolism & Mechanism of Action & Ref. \\
\hline \multicolumn{6}{|l|}{ In vitro studies } \\
\hline HepG2 cells & $24 \mathrm{~h}$ & $\uparrow$ & FAS mRNA & Genomic & {$[28]$} \\
\hline HepG2 cells & Up to $24 \mathrm{~h}$ & $\uparrow$ & SREBP-1 protein synthesis & Non genomic & [30] \\
\hline Hepatocytes from eu- and hypothyroid rats fed chow diet & $4 \mathrm{~h}$ & $\uparrow$ & $\begin{array}{l}\text { Synthesis of fatty acids and their incorporation } \\
\text { into lipid fractions }\end{array}$ & Not reported & {$[62]$} \\
\hline Cultured hepatocytes from chick embryo & Up to $49 \mathrm{~h}$ & $\uparrow$ & ACC promoter activity and mRNA abundance & Genomic & {$[66,67]$} \\
\hline Cultured hepatocytes from chick embryo & Up to $48 \mathrm{~h}$ & $\uparrow$ & $\begin{array}{l}\text { ME, FAS, ACC enzyme activity and } \\
\text { mRNA abundance }\end{array}$ & Genomic & {$[71,76]$} \\
\hline Hepatocytes from hypothyroid rats & $24 \mathrm{~h}$ & $\uparrow$ & ACLY protein level and activity & Not reported & [82] \\
\hline HepG2 cells & $24 \mathrm{~h}$ & $\uparrow$ & ME promoter activity & Genomic & [83] \\
\hline \multicolumn{6}{|l|}{ In vivo studies } \\
\hline Liver from eu- and hyperthyroid rats fed chow diet. & 4 weeks & $\uparrow$ & SREBP-1 protein level & Not reported & [30] \\
\hline Liver from eu- and hypothyroid rats fed chow diet & 4 weeks & $\uparrow$ & $\begin{array}{l}\text { Mitochondrial citrate carrier expression, nuclear } \\
\text { transcription rate and splicing efficiency }\end{array}$ & Genomic & {$[53,54]$} \\
\hline Liver from eu- and hyperthyroid rats fed fat-enriched chow diet. & 7 days & $\uparrow$ & Fatty acid synthesis & Not reported & [63] \\
\hline Liver from hypo- and hyperthyroid rats fed chow diet. & 7 days & $\uparrow$ & ACC mRNA abundance & Not reported & [69] \\
\hline Liver from eu-, hypo- and hyperthyroid mice fed chow diet. & 5 days & $\downarrow$ & $\begin{array}{l}\text { SREBP-1 mRNA abundance and SREBP-1 } \\
\text { promoter activity }\end{array}$ & Genomic & [74] \\
\hline Liver from eu-, hypo- and hyperthyroid mice fed chow diet. & 5 days & $\uparrow$ & $\begin{array}{l}\text { ChREBP mRNA abundance and protein level; } \\
\text { ChREBP promoter activity }\end{array}$ & Genomic & {$[77]$} \\
\hline $\begin{array}{l}\text { Liver from eu- and hyperthyroid mice fed chow diet or high } \\
\text { carbohydrate diet. }\end{array}$ & Not reported & $\uparrow$ & $\begin{array}{l}\text { ChREBP mRNA abundance; ChREBP promoter } \\
\text { activity }\end{array}$ & Genomic & {$[78]$} \\
\hline $\begin{array}{l}\text { Liver from eu-, hypo-, and hyperthyroid rats, starved and refed } \\
\text { on carbohydrate-rich diet }\end{array}$ & 7 days & $\uparrow$ & G6PD enzyme activity & Non genomic & {$[85]$} \\
\hline $\begin{array}{l}\text { Liver from eu- and hyperthyroid rats fed chow diet or high } \\
\text { carbohydrate, fat-free diet. }\end{array}$ & 7 days & $\uparrow$ & ME mRNA abundance and enzyme activity & Not reported & {$[92]$} \\
\hline $\begin{array}{l}\text { Liver from eu- and hyperthyroid rats fed chow diet or high } \\
\text { carbohydrate, fat-free diet. }\end{array}$ & 7 days & $\uparrow$ & $\begin{array}{l}\text { ME, G6PD and 6PGD enzyme activity, mRNA } \\
\text { abundance and relative rate of enzyme synthesis }\end{array}$ & $\begin{array}{l}\text { Genomic and } \\
\text { non-genomic }\end{array}$ & [95] \\
\hline Liver from hypo- and hyperthyroid rats fed chow diet & Up to $4 \mathrm{~h}$ & $\uparrow$ & Spot 14 protein (S14) mRNA abundance & Not reported & [96] \\
\hline Liver from eu- and hyperthyroid rats fed chow diet & 1 day & $\uparrow$ & Induction of citrate carrier activity & Not reported & [80] \\
\hline
\end{tabular}

$\downarrow$ Decrease; $\uparrow$ Increase. 


\section{T2 and Its Effects on DNL}

It has been reported that T2, previously considered only a T3 catabolite, is able to increase significantly the BMR, and greatly reduces adiposity and dyslipidemia without inducing unfavourable side effects (thyrotoxicosis) [17,19,104].

In rats fed on high fat diet, T2 prevents the pathways leading to lipid storage in lipid droplets (LDs), promotes the processes of lipid mobilization from LDs and secretion as VLDL [105] (Table 2). In in vitro model of hepatosteatosis, T2 stimulates the mitochondrial oxidation by up-regulating carnitine-palmitoyl-transferase (CPT1), uncoupling protein 2 (UCP2) and very long-chain acyl-coenzyme A dehydrogenase (VLCAD) [106]. By activating mitochondrial oxidative metabolism of fatty acids, in particular of saturated fatty acids, T2 reduces the number and size of LDs, and modifies their acyl composition by decreasing the content of saturated vs. monounsaturated fatty acids [106] (Table 2).

Unlike T3 whose action in stimulating lipogenesis is mainly mediated through TR $\beta$, T2 has a reduced binding capacity to human TR $\beta$ [107] and shows a weak transactivating capacity of TR $\beta$ target genes in different systems $[17,104,107]$.

T2 carries out its antilipidemic effects by concomitantly activating fatty acid oxidation and down regulating lipogenesis $[103,108]$ (Figure 2). This is achieved through the activation of two factors involved in lipid metabolism: AMPK and nuclear deacetylase sirtuin 1 (SIRT1) [103].

AMPK is a known detector of cellular ATP levels [109], and it acts as a master sensor of the energy status of the cell [110]. When activated via phosphorylation, AMPK phosphorylates, in turn, ACC that results inactivated: this state determines the down regulation of DNL (Figure 2); furthermore, the resulting reduced formation of malonyl-CoA causes the activation of CPT I and, as a consequence, the increase in fatty acid oxidation [111] (Figure 2).

Sirtuins are a group of histone/protein deacetylases regulated by variations in the cellular $\mathrm{NAD}^{+}$/NADH ratio. SIRT1, the most studied member of this family, responds to overfeeding, starvation, changes in energy expenditure and muscular exercise [112]. SIRT1 and AMPK can activate reciprocally, revealing the existence of an AMPK-SIRT1 cycle that links the cell energy to the redox states [112]. In addition, AMPK and SIRT1 (and most likely other sirtuins) act on common transcriptional activators and coactivators, including the mitochondrial master regulator PGC1 $\alpha$ and members of the FoxO family [112]. It has been reported that $\mathrm{T} 2$ administration to high fat-fed rats determines a rapid and persistent activation of SIRT1 in liver [104,108] (Figure 2, Table 2). T2-activated SIRT1 catalyses the deacetylation of SREBP-1 and PGC1 $\alpha$ causing their inactivation and activation, respectively. As a consequence of SREBP-1 inactivation, a down regulation of hepatic lipogenesis in high fat-fed rats was observed [104,108]. On the other hand, the SIRT1-mediated activation of PGC1 $\alpha$ is correlated with the rapid induction of hepatic fatty acid oxidation in T2-treated rats [104,108]. Recently, the positive effects of T2 treatment on body lipid composition, characterized by the reduction of different fat depots and the increment of metabolic rate have been observed in obese mice [113]. However, the authors indicated that these positive effects were partially compromised by hyperphagia, which prevented weight loss in diet-induced obese mice [113]. It has been reported that $\mathrm{T} 2$, at pharmacological doses, inhibits lipogenesis in human HepG2 cells [114]. This effect is due to the block of the SREBP-1 activating cleavage, subsequent to the activation of ERK, p38, Akt and PKC- $\delta$ (Figure 2). The inhibition of SREBP-1 decreases, in turn, the expression of $F A S$, its target gene. Furthermore, all these cellular events, induced by T2, trigger caspase 3-dependent apoptosis of cultured HepG2 cells [115] (Figure 2). 
Table 2. Relevant effects of T2 on hepatic fatty acid metabolism.

\begin{tabular}{|c|c|c|c|}
\hline Experimental Model & Time of Treatment & Effect of T2 on Lipid Metabolism & Ref. \\
\hline \multicolumn{4}{|l|}{ In vitro studies } \\
\hline $\begin{array}{l}\text { FaO cells rendered steatotic by } \\
\text { incubation of free fatty acids }\end{array}$ & $24 \mathrm{~h}$ & $\begin{array}{l}\text { Reduction in the number and size of lipid droplets in steatotic cells } \\
\text { as consequence of triacylglycerols mobilization from lipid droplets. } \\
\text { Stimulation of mitochondrial oxidative metabolism of fatty acids. }\end{array}$ & [106] \\
\hline HepG2 cells & Up to $48 \mathrm{~h}$ & $\begin{array}{l}\text { Induction of SREBP-1 proteolytic cleavage block and apoptosis in } \\
\text { human hepatoma. }\end{array}$ & [114] \\
\hline \multicolumn{4}{|l|}{ In vivo studies } \\
\hline $\begin{array}{l}\text { Liver from eu- and T2-treated rats fed } \\
\text { chow diet or high fat diet }\end{array}$ & Up to 4 weeks & $\begin{array}{l}\text { Reduction of hepatic fatty accumulation induced by a high-fat diet. } \\
\text { Induction of fatty acid oxidation rate and of CPT I activity. }\end{array}$ & {$[20]$} \\
\hline $\begin{array}{l}\text { Liver from hypo-, eu- and T2-treated } \\
\text { hypothyroid rats fed chow diet }\end{array}$ & $1 \mathrm{~h}$ & Increment of CPT-I activity and of total rate of fatty acid oxidation. & [15] \\
\hline $\begin{array}{l}\text { Liver from eu- and T2-treated rats fed } \\
\text { chow diet or high fat diet }\end{array}$ & Up to 4 weeks & $\begin{array}{l}\text { Deacetylation of peroxisome proliferator-activated receptor } \\
\text { (PPAR)- } \gamma \text { and of SREBP-1 through the activation of SIRT1. } \\
\text { Up-regulation of genes involved in the mitochondrial biogenesis and } \\
\text { down-regulation of lipogenic genes. }\end{array}$ & [104] \\
\hline $\begin{array}{l}\text { Liver from eu- and T2-treated rats fed } \\
\text { chow diet or high fat diet }\end{array}$ & 30 days & $\begin{array}{l}\text { Prevention of pathways leading to lipid storage in lipid droplets. } \\
\text { Mobilization of lipids from lipid droplets and secretion as VLDL. }\end{array}$ & [105] \\
\hline
\end{tabular}




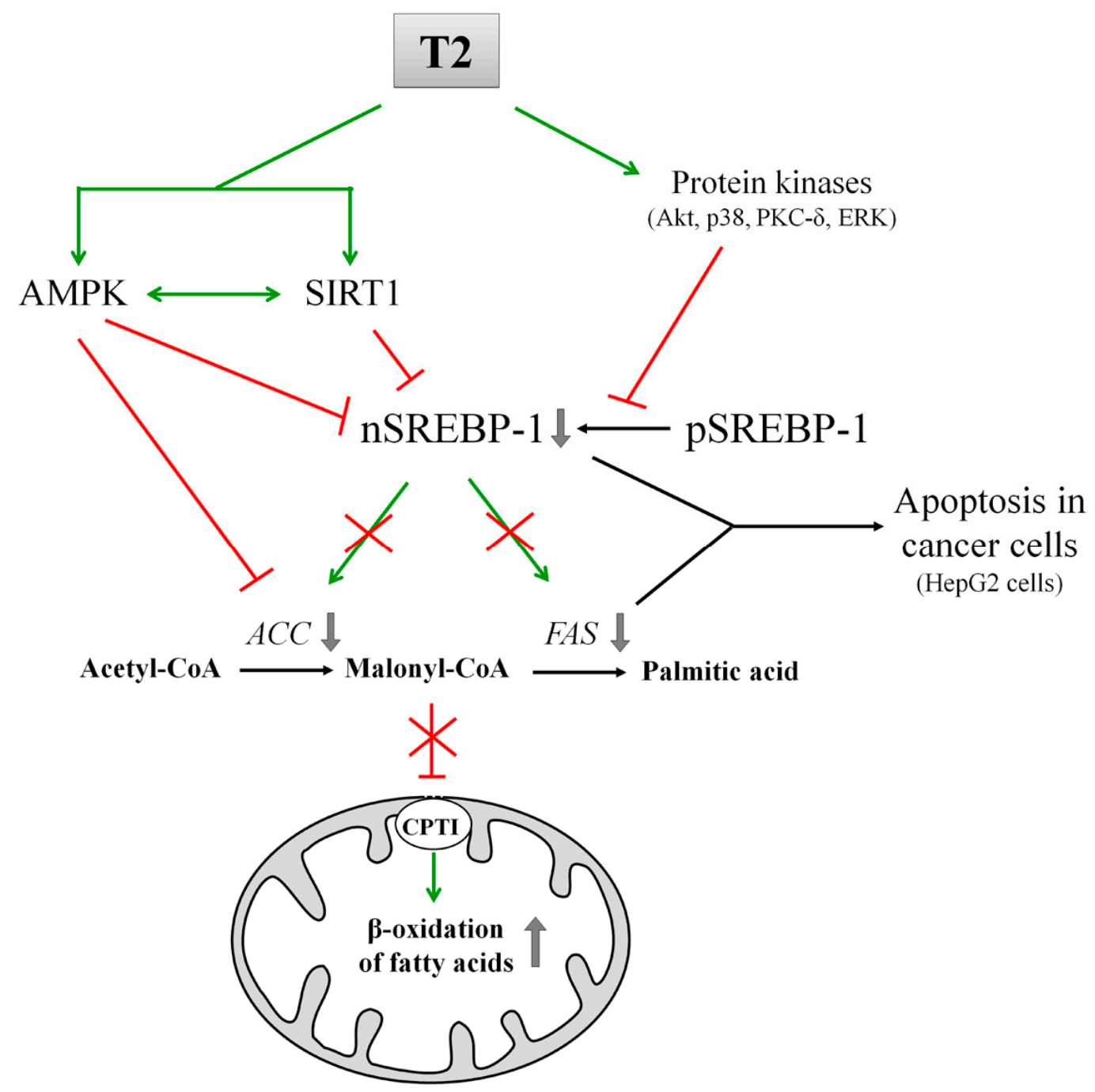

Figure 2. Scheme of the inhibition of fatty acid synthesis mediated by T2. Green line-arrow, Stimulation; Red T-bar, Inhibition; Red cross, Loss of stimulation/inhibition consequent to T2 action. Abbreviations: ACC, Acetyl-CoA carboxylase; AMPK, AMP-activated protein kinase; CPTI, Carnitine palmitoyltransferase I; FAS, Fatty acid synthase; nSREBP-1, nuclear sterol regulatory element-binding protein 1; pSREBP-1, precursor sterol regulatory element-binding protein 1; SIRT1, Sirtuin 1.

Taken together, these findings suggest that $\mathrm{T} 2$ seems to be more effective with respect to $\mathrm{T} 3 \mathrm{in}$ lowering hepatic fat accumulation. Indeed, while T2 down regulates lipogenesis through SREBP-1 inhibition [104,114], T3 increases hepatic lipogenesis, even upon activation of SREBP-1 expression [29]. It has been shown that T2 prevents diet induced obesity [19], reduces liver steatosis in rodents [20], increases the resting metabolic rate and reduces body weight gain in humans [115]. Since T2 action occurs without thyromimetic side effects typically associated with T3 administration, T2 has been proposed as a potential hypolipidemic drug as well as a drug for the treatment of diet-induced obesity and hepatic steatosis in humans [115]. However, a very recent study raised concern about indiscriminate administration of T2 for the treatment of hyperlipidemia and pandemic obesity in humans [113]. Enlarged heart weights has been observed after T2 treatment, indicating potential cardiac side effects of this hormone [113]. Therefore, further studies are needed for a careful analysis of T2 mechanisms of action and safety. 


\section{Conclusions and Future Perspectives}

The bulk of the literature about THs is focused on their effectiveness in reducing body weight, in counteracting visceral fat accumulation as well as hepatosteatosis, serum TAGs and cholesterol levels, and insulin resistance. Although THs can stimulate hepatic lipogenesis, prolonged THs treatment leads to the increase of FA oxidation and metabolic rate. For these reasons, it has been proposed the use of THs (T4 and T3) as therapeutic agents against obesity and correlated pathologies such as dyslipidemia, hepatic steatosis and cardiovascular disorders. The onset of thyrotoxic states (heart failure, loss of bone and muscle mass, fatigue) severely limits their clinical use, driving research in the development of TRs agonists and THs analogs with an adequate lipid-lowering and antiobesity efficacy, without thyrotoxic effects. In this context, growing is the interest for T2, able of an excellent lipid lowering action without the above mentioned side effects.

The goal of the present review was to focus the attention of the readers on T3 and its natural derivative $\mathrm{T} 2$, and on their action on liver fatty acid metabolism, highlighting the differences among them. T2 seems to be not properly a thyromimetic: while T3 stimulates both hepatic lipogenesis and fatty acid oxidation, T2 induces fatty acid oxidation and inhibits lipogenesis. Furthermore, as above described, there are other significant differences between the two hormones, concerning their molecular mechanisms of action.

Finally, it is interesting to correlate T2 ability to the down-regulation of lipogenesis and to the induction of apoptosis recently reported in HepG2 cells (Figure 2). The latter effect can be ascribed to the block of SREBP-1 proteolytic cleavage and to the FAS down regulation [114] (Figure 2). Accordingly, several in vivo and in vitro studies reported that pharmacological inhibition of SREBP-1 cleavage and of FAS activity, as well as silencing of FAS expression, induces apoptosis in cancer cells [116].

Indeed, FAS and SREBPs are considered key factors involved in neoplastic lipogenesis. Their overexpression is common to many cancers, and accumulating lines of evidence suggest that they are metabolic oncogenes with an important role in tumour growth and survival, making them attractive targets for cancer therapy [117]. Nowadays, there is a great interest for studies aimed at the development of new drugs and therapies to control the expression of FAS and SREBP-1. These observations highlight the possible use of the non-thyrotoxic hormone T2 as an inhibitor of lipogenic genes expression and activator of apoptosis, selectively in cancer cells.

Conflicts of Interest: The authors declare no conflict of interest.

$\begin{array}{ll}\text { Abbreviations } & \\ \text { 6PGD } & \text { 6-Phosphogluconate dehydrogenase } \\ \text { ACC } & \text { Acetyl-CoA carboxylase } \\ \text { ACLY } & \text { ATP citrate lyase } \\ \text { AMPK } & \text { Protein kinase AMP-activated } \\ \text { BMR } & \text { Basal metabolic rate } \\ \text { ChREBP } & \text { Carbohydrate response element binding protein } \\ \text { CPT I } & \text { Carnitine palmitoyltransferase I } \\ \text { CPT II } & \text { Carnitine palmitoyltransferase II } \\ \text { CiC } & \text { Mitochondrial citrate carrier } \\ \text { DNL } & \text { De novo lipogenesis } \\ \text { ER } & \text { Endoplasmic reticulum } \\ \text { ERK1/2 } & \text { Extracellular-signal regulated kinases 1/2 } \\ \text { FA } & \text { Fatty acids } \\ \text { FAS } & \text { Fatty acid synthase } \\ \text { FoxO } & \text { Forkhead box O } \\ \text { G6PD } & \text { Glucose-6-phosphate dehydrogenase } \\ \text { IMM } & \text { Inner mitochondrial membrane } \\ \text { INSIG } & \text { Insulin-induced gene } \\ \text { IRES } & \text { Internal ribosome entry site } \\ \end{array}$




$\begin{array}{ll}\text { L-PK } & \text { Liver pyruvate kinase } \\ \text { LDs } & \text { Lipid droplets } \\ \text { MAPK } & \text { Mitogen-activated protein kinase } \\ \text { ME } & \text { Malic enzyme } \\ \text { MLX } & \text { Max-like protein } X \\ \text { MPC } & \text { Mitochondrial pyruvate carrier } \\ \text { mTOR } & \text { Mechanistic target of rapamycin } \\ \text { OAA } & \text { Oxalacetate } \\ \text { P38 } & \text { P38 mitogen-activated protein kinase } \\ \text { PGC1 } \alpha & \text { Peroxisome proliferative activated receptor } \gamma \text { coactivator } 1 \alpha \\ \text { PI3K } & \text { Phosphoinositide 3-kinase } \\ \text { PKB /Akt } & \text { Protein kinase B/serine/threonine kinase } 1 \\ \text { PKC } & \text { Protein kinase C } \\ \text { PKM2 } & \text { M2 isoform of pyruvate kinase } \\ \text { RXR } & \text { Retinoid X receptor } \\ \text { S14 } & \text { Spot } 14 \\ \text { SCAP } & \text { SREBP-cleavage-activating protein } \\ \text { SIRT1 } & \text { Sirtuin } 1 \\ \text { SREBPs } & \text { Sterol regulatory element-binding proteins } \\ \text { TAGs } & \text { Triacylglycerols } \\ \text { TRE } & \text { T3 responsive element } \\ \text { T2 } & 3,5 \text {-Diiodo-L-thyronine } \\ \text { T3 } & 3,5,3^{\prime} \text {-Triiodo-L-thyronine } \\ \text { T4 } & 3,3^{\prime}, 5,5^{\prime} \text {-Tetraiodo-L-thyronine } \\ \text { TCA } & \text { Tricarboxylic acid } \\ \text { THs } & \text { Thyroid hormones } \\ \text { TR } \alpha 1 & \text { Thyroid hormone receptor- } \alpha 1 \\ \text { TR } \beta 1 & \text { Thyroid hormone receptor- } \beta 1 \\ \text { TR } \beta 2 & \text { Thyroid hormone receptor- } \beta 2 \\ \text { TRs } & \text { Thyroid receptors } \\ \text { VLDL } & \text { Very low density lipoprotein } \\ & \end{array}$

\section{References}

1. Orozco, A.; Valverde, R.C.; Olvera, A.; García, G.C. Iodothyronine deiodinases: A functional and evolutionary perspective. J. Endocrinol. 2012, 215, 207-219. [CrossRef] [PubMed]

2. Gnocchi, D.; Steffensen, K.R.; Bruscalupi, G.; Parini, P. Emerging role of thyroid hormone metabolites. Acta Physiol. 2016, 217, 184-216. [CrossRef] [PubMed]

3. Johansson, L.; Rudling, M.; Scanlan, T.S.; Lundasen, T.; Webb, P.; Baxter, J.; Angelin, B.; Parini, P. Selective thyroid receptor modulation by GC-1 reduces serum lipids and stimulates steps of reverse cholesterol transport in euthyroid mice. Proc. Natl. Acad. Sci. USA 2005, 102, 10297-10302. [CrossRef] [PubMed]

4. Mörk, L.M.; Rehnmark, S.; Davoodpour, P.; Norata, G.D.; Larsson, L.; Witt, M.R.; Malm, J.; Parini, P. The thyroid receptor modulator KB3495 reduces atherosclerosis independently of total cholesterol in the circulation in ApoE deficient mice. PLoS ONE 2013, 8, e78534. [CrossRef] [PubMed]

5. Brenta, G. Why can insulin resistance be a natural consequence of thyroid dysfunction? J. Thyroid Res. 2011, 2011, 152850. [CrossRef] [PubMed]

6. Laville, M.; Khalfallah, Y.; Vidal, H.; Beylot, M.; Comte, B.; Riou, J.P. Hormonal control of glucose production and pyruvate kinase activity in isolated rat liver cells: Influence of hypothyroidism. Mol. Cell. Endocrinol. 1987, 50, 247-253. [CrossRef]

7. Mullur, R.; Liu, Y.Y.; Brent, G.A. Thyroid hormone regulation of metabolism. Physiol. Rev. 2014, 94, 355-382. [CrossRef] [PubMed]

8. Müller, M.J.; Seitz, H.J. Thyroid hormone action on intermediary metabolism. Part III. Protein metabolism in hyper- and hypothyroidism. Klin. Wochenschr. 1984, 62, 97-102. [CrossRef] [PubMed]

9. Goglia, F.; Moreno, M.; Lanni, A. Action of thyroid hormones at the cellular level: The mitochondrial target. FEBS Lett. 1999, 452, 115-120. [CrossRef] 
10. Senatore, V.; Cione, E.; Gnoni, A.; Genchi, G. Retinoylation reactions are inversely related to the cardiolipin level in testes mitochondria from hypothyroid rats. J. Bioenerg. Biomembr. 2010, 42, 321-328. [CrossRef] [PubMed]

11. Goglia, F. Biological effects of 3,5-diiodothyronine $\left(\mathrm{T}_{2}\right)$. Biochemistry 2005, 70, 164-172. [CrossRef] [PubMed]

12. Horst, C.; Rokos, H.; Seitz, H.J. Rapid stimulation of hepatic oxygen consumption by 3,5-di-iodo-L-thyronine. Biochem. J. 1989, 261, 945-950. [CrossRef] [PubMed]

13. Giudetti, A.M.; Leo, M.; Geelen, M.J.; Gnoni, G.V. Short-term stimulation of lipogenesis by 3,5-L-diiodothyronine in cultured rat hepatocytes. Endocrinology 2005, 146, 3959-3966. [CrossRef] [PubMed]

14. Cavallo, A.; Gnoni, A.; Conte, E.; Siculella, L.; Zanotti, F.; Papa, S.; Gnoni, G.V. 3,5-Diiodo-L-thyronine increases FoF1-ATP synthase activity and cardiolipin level in liver mitochondria of hypothyroid rats. J. Bioenerg. Biomembr. 2011, 43, 349-357. [CrossRef] [PubMed]

15. Cavallo, A.; Priore, P.; Gnoni, G.V.; Papa, S.; Zanotti, F.; Gnoni, A. 3,5-Diiodo-L-thyronine administration to hypothyroid rats rapidly enhances fatty acid oxidation rate and bioenergetic parameters in liver cells. PLoS ONE 2013, 8, e52328. [CrossRef] [PubMed]

16. Cioffi, F.; Lanni, A.; Goglia, F. Thyroid hormones, mitochondrial bioenergetics and lipid handling. Curr. Opin. Endocrinol. Diabetes Obes. 2010, 17, 402-407. [CrossRef] [PubMed]

17. Senese, R.; Cioffi, F.; de Lange, P.; Goglia, F.; Lanni, A. Thyroid: Biological actions of "nonclassical" thyroid hormones. J. Endocrinol. 2014, 221, R1-R12. [CrossRef] [PubMed]

18. Cavallo, A.; Taurino, F.; Damiano, F.; Siculella, L.; Sardanelli, A.M.; Gnoni, A. Acute administration of 3,5-diiodo-L-thyronine to hypothyroid rats stimulates bioenergetic parameters in liver mitochondria. J. Bioenerg. Biomembr. 2016, 48, 521-529. [CrossRef] [PubMed]

19. Lanni, A.; Moreno, M.; Lombardi, A.; de Lange, P.; Silvestri, E.; Ragni, M.; Farina, P.; Baccari, G.C.; Fallahi, P.; Antonelli, A.; et al. 3,5-Diiodothyronine powerfully reduces adiposity by increasing the burning of fats. FASEB J. 2005, 19, 1552-1554. [PubMed]

20. Mollica, M.P.; Lionetti, L.; Moreno, M.; Lombardi, A.; de Lange, P.; Antonelli, A.; Lanni, A.; Cavaliere, G.; Barletta, A.; Goglia, F. 3,5-Diiodo-L-thyronine, by modulating mitochondrial functions, reverses hepatic fat accumulation in rats fed a high-fat diet. J. Hepatol. 2009, 51, 363-370. [CrossRef] [PubMed]

21. Grasselli, E.; Voci, A.; Canesi, L.; de Matteis, R.; Goglia, F.; Cioffi, F.; Fugassa, E.; Gallo, G.; Vergani, L. Direct effects of iodothyronines on excess fat storage in rat hepatocytes. J. Hepatol. 2011, 54, 1230-1236. [CrossRef] [PubMed]

22. Upadhyay, G.; Singh, R.; Kumar, A.; Kumar, S.; Kapoor, A.; Godbole, M.M. Severe hyperthyroidism induces mitochondria-mediated apoptosis in rat liver. Hepatology 2004, 39, 1120-1130. [CrossRef] [PubMed]

23. Fernández-Vizarra, E.; Enriquez, J.A.; Pérez-Martos, A.; Montoya, J.; Fernández-Silva, P. Mitochondrial gene expression is regulated at multiple levels and differentially in the heart and liver by thyroid hormones. Curr. Genet. 2008, 54, 13-22. [CrossRef] [PubMed]

24. Mangiullo, R.; Gnoni, A.; Damiano, F.; Siculella, L.; Zanotti, F.; Papa, S.; Gnoni, G.V. 3,5-Diiodo-L-thyronine upregulates rat-liver mitochondrial $\mathrm{F}_{\mathrm{o}} \mathrm{F}_{1}$-ATP synthase by GA-binding protein/nuclear respiratory factor-2. Biochim. Biophys. Acta 2010, 1797, 233-240. [CrossRef] [PubMed]

25. Cheng, S.Y.; Leonard, J.L.; Davis, P.J. Molecular aspects of thyroid hormone actions. Endocr. Rev. 2010, 31, 139-170. [CrossRef] [PubMed]

26. Yen, P.M. Physiological and molecular basis of thyroid hormone action. Physiol. Rev. 2001, 81, $1097-1142$. [PubMed]

27. Hennemann, G.; Docter, R.; Friesema, E.C.; de Jong, M.; Krenning, E.P.; Visser, T.J. Plasma membrane transport of thyroid hormones and its role in thyroid hormone metabolism and bioavailability. Endocr. Rev. 2001, 22, 451-476. [CrossRef] [PubMed]

28. Radenne, A.; Akpa, M.; Martel, C.; Sawadogo, S.; Mauvoisin, D.; Mounier, C. Hepatic regulation of fatty acid synthase by insulin and T3: Evidence for T3 genomic and nongenomic actions. Am. J. Physiol. Endocrinol. Metab. 2008, 295, E884-E894. [CrossRef] [PubMed]

29. Davis, P.J.; Leonard, J.L.; Davis, F.B. Mechanisms of nongenomic actions of thyroid hormone. Front. Neuroendocrinol. 2008, 29, 211-821. [CrossRef] [PubMed]

30. Gnoni, G.V.; Rochira, A.; Leone, A.; Damiano, F.; Marsigliante, S.; Siculella, L. 3,5,3'-Triiodo-L-thyronine induces SREBP-1 expression by non-genomic actions in human HEP G2 cells. J. Cell. Physiol. 2012, 227, 2388-2397. [CrossRef] [PubMed] 
31. Plow, E.F.; Haas, T.A.; Zhang, L.; Loftus, J.; Smith, J.W. Ligand binding to integrins. J. Biol. Chem. 2000, 275, 21785-21788. [CrossRef] [PubMed]

32. Arnaout, M.A.; Goodman, S.L.; Xiong, J.P. Coming to grips with integrin binding to ligands. Curr. Opin. Cell Biol. 2002, 14, 641-651. [CrossRef]

33. Bergh, J.J.; Lin, H. Y.; Lansing, L.; Mohamed, S.N.; Davis, F.B.; Mousa, S.; Davis, P.J. Integrin $\alpha \mathrm{V} \beta 3$ contains a cell surface receptor site for thyroid hormone that is linked to activation of mitogen-activated protein kinase and induction of angiogenesis. Endocrinology 2005, 146, 2864-2871. [CrossRef] [PubMed]

34. Davis, P.J.; Shih, A.; Lin, H.Y.; Martino, L.J.; Davis, F.B. Thyroxine promotes association of mitogen-activated protein kinase and nuclear thyroid hormone receptor (TR) and causes serine phosphorylation of TR. J. Biol. Chem. 2000, 275, 38032-38039. [CrossRef] [PubMed]

35. De Lange, P.; Senese, R.; Cioffi, F.; Moreno, M.; Lombardi, A.; Silvestri, E.; Goglia, F.; Lanni, A. Rapid activation by 3,5,3'-L-triiodothyronine of adenosine $5^{\prime}$-monophosphate-activated protein kinase/acetyl-coenzyme a carboxylase and Akt/protein kinase B signaling pathways: Relation to changes in fuel metabolism and myosin heavy-chain protein content in rat gastrocnemius muscle in vivo. Endocrinology 2008, 149, 6462-6470. [PubMed]

36. Cao, X.; Kambe, F.; Moeller, L.C.; Refetoff, S.; Seo, H. Thyroid hormone induces rapid activation of Akt/protein kinase B-mammalian target of rapamycin-p70S6K cascade through phosphatidylinositol 3-kinase in human fibroblasts. Mol. Endocrinol. 2005, 19, 102-112. [CrossRef] [PubMed]

37. Kavok, N.S.; Krasilnikova, O.A.; Babenko, N.A. Thyroxine signal transduction in liver cells involves phospholipase C and phospholipase D activation. Genomic independent action of thyroid hormone. BMC Cell Biol. 2001, 2, 5. [CrossRef]

38. Eaton, S. Control of mitochondrial $\beta$-oxidation flux. Prog. Lipid. Res. 2002, 41, 197-239. [CrossRef]

39. Paradies, G.; Papa, S. On the kinetics and substrate specificity of the pyruvate translocator in rat liver mitochondria. Biochim. Biophys. Acta 1977, 462, 333-346. [CrossRef]

40. Glerum, D.M.; Claeys, D.; Mertens, W.; Azzi, A. The tricarboxylate carrier from rat liver mitochondria. Purification, reconstitution and kinetic characterization. Eur. J. Biochem. 1990, 194, 681-684. [CrossRef] [PubMed]

41. Gnoni, G.V.; Priore, P.; Geelen, M.J.; Siculella, L. The mitochondrial citrate carrier: Metabolic role and regulation of its activity and expression. IUBMB Life 2009, 61, 987-994. [CrossRef] [PubMed]

42. Palmieri, F. Mitochondrial transporters of the SLC25 family and associated diseases: A review. J. Inherit. Metab. Dis. 2014, 37, 565-575. [CrossRef] [PubMed]

43. Brownsey, R.W.; Boone, A.N.; Elliott, J.E.; Kulpa, J.E.; Lee, W.M. Regulation of acetyl-CoA carboxylase. Biochem. Soc. Trans. 2006, 34, 223-227. [CrossRef] [PubMed]

44. Kim, K.-H. Regulation of mammalian acetyl coenzyme A carboxylase. Annu. Rev. Nutr. 1997, 17, 77-99. [CrossRef] [PubMed]

45. Jensen-Urstad, A.P.; Semenkovich, C.F. Fatty acid synthase and liver triglyceride metabolism: Housekeeper or messenger? Biochim. Biophys. Acta 2012, 182, 747-753. [CrossRef] [PubMed]

46. Gnoni, A.; Giudetti, A.M. Dietary long-chain unsaturated fatty acids acutely and differently reduce the activities of lipogenic enzymes and of citrate carrier in rat liver. J. Physiol. Biochem. 2016, 72, 485-494. [CrossRef] [PubMed]

47. Azzi, A.; Glerum, M.; Koller, R.; Mertens, W.; Spycher, S. The mitochondrial tricarboxylate carrier. J. Bioenerg. Biomembr. 1993, 25, 515-524. [CrossRef] [PubMed]

48. Giudetti, A.M.; Sabetta, S.; di Summa, R.; Leo, M.; Damiano, F.; Siculella, L.; Gnoni, G.V. Differential effects of coconut oil- and fish oil-enriched diets on tricarboxylate carrier in rat liver mitochondria. J. Lipid Res. 2003, 44, 2135-2141. [CrossRef] [PubMed]

49. Siculella, L.; Damiano, F.; Sabetta, S.; Gnoni, G.V. n-6 PUFAs downregulate expression of the tricarboxylate carrier in rat liver by transcriptional and posttranscriptional mechanisms. J. Lipid Res. 2004, 45, 1333-1340. [CrossRef] [PubMed]

50. Siculella, L.; Sabetta, S.; Damiano, F.; Giudetti, A.M.; Gnoni, G.V. Different dietary fatty acids have dissimilar effects on activity and gene expression of mitochondrial tricarboxylate carrier in rat liver. FEBS Lett. 2004, 578, 280-284. [CrossRef] [PubMed]

51. Damiano, F.; Gnoni, G.V.; Siculella, L. Functional analysis of rat liver citrate carrier promoter: Differential responsiveness to polyunsaturated fatty acids. Biochem. J. 2009, 417, 561-571. [CrossRef] [PubMed] 
52. Damiano, F.; Mercuri, E.; Stanca, E.; Gnoni, G.V.; Siculella, L. Streptozotocin-induced diabetes affects in rat liver citrate carrier gene expression by transcriptional and posttranscriptional mechanisms. Int. J. Biochem. Cell Biol. 2011, 43, 1621-1629. [CrossRef] [PubMed]

53. Giudetti, A.M.; Leo, M.; Siculella, L.; Gnoni, G.V. Hypothyroidism down-regulates mitochondrial citrate carrier activity and expression in rat liver. Biochim. Biophys. Acta 2006, 1761, 484-491. [CrossRef] [PubMed]

54. Siculella, L.; Sabetta, S.; Giudetti, A.M.; Gnoni, G.V. Hypothyroidism reduces tricarboxylate carrier activity and expression in rat liver mitochondria by reducing nuclear transcription rate and splicing efficiency. J. Biol. Chem. 2006, 281, 19072-19080. [CrossRef] [PubMed]

55. Gnoni, G.V.; Giudetti, A.M.; Mercuri, E.; Damiano, F.; Stanca, E.; Priore, P.; Siculella, L. Reduced activity and expression of mitochondrial citrate carrier in streptozotocin-induced diabetic rats. Endocrinology 2010, 151, 1551-1559. [CrossRef] [PubMed]

56. Damiano, F.; Tocci, R.; Gnoni, G.V.; Siculella, L. Expression of citrate carrier gene is activated by ER stress effectors XBP1 and ATF6 $\alpha$, binding to an UPRE in its promoter. Biochim. Biophys. Acta 2015, 1849, $23-31$. [CrossRef] [PubMed]

57. Takeuchi, H.; Nakamoto, T.; Mori, Y.; Kawakami, M.; Mabuchi, H.; Ohishi, Y.; Ichikawa, N.; Koike, A.; Masuda, K. Comparative effects of dietary fat types on hepatic enzyme activities related to the synthesis and oxidation of fatty acid and to lipogenesis in rats. Biosci. Biotechnol. Biochem. 2001, 65, 1748-1754. [CrossRef] [PubMed]

58. Horton, J.D. Sterol regulatory element-binding proteins: Transcriptional activators of lipid synthesis. Biochem. Soc. Trans. 2002, 30, 1091-1095. [CrossRef] [PubMed]

59. Iizuka, K. Recent progress on the role of ChREBP in glucose and lipid metabolism. Endocr. J. 2013, 60, 543-555. [CrossRef] [PubMed]

60. Jeon, T.I.; Osborne, T.F. SREBPs: Metabolic integrators in physiology and metabolism. Trends Endocrinol. Metab. 2012, 23, 65-72. [CrossRef] [PubMed]

61. Kawaguchi, T.; Takenoshita, M.; Kabashima, T.; Uyeda, K. Glucose and cAMP regulate the L-type pyruvate kinase gene by phosphorylation/dephosphorylation of the carbohydrate response element binding protein. Proc. Natl. Acad. Sci. USA 2001, 98, 13710-13715. [CrossRef] [PubMed]

62. Gnoni, G.V.; Geelen, M.J.; Bijleveld, C.; Quagliariello, E.; van den Bergh, S.G. Short-term stimulation of lipogenesis by triiodothyronine in maintenance cultures of rat hepatocytes. Biochem. Biophys. Res. Commun. 1985, 128, 525-530. [CrossRef]

63. Clarke, S.D.; Hembree, J. Inhibition of triiodothyronine's induction of rat liver lipogenic enzymes by dietary fat. J. Nutr. 1990, 120, 625-630. [PubMed]

64. Blennemann, B.; Moon, Y.K.; Freake, H.C. Tissue-specific regulation of fatty acid synthesis by thyroid hormone. Endocrinology 1992, 130, 637-643. [PubMed]

65. Huang, C.; Freake, H.C. Thyroid hormone regulates the acetyl-CoA carboxylase PI promoter. Biochem. Biophys. Res. Commun. 1998, 249, 704-708. [CrossRef] [PubMed]

66. Hillgartner, F.B.; Charron, T.; Chesnut, K.A. Triiodothyronine stimulates and glucagon inhibits transcription of the acetyl-CoA carboxylase gene in chick embryo hepatocytes: Glucose and insulin amplify the effect of triiodothyronine. Arch. Biochem. Biophys. 1997, 337, 159-168. [CrossRef] [PubMed]

67. Zhang, Y.; Yin, L.; Hillgartner, F.B. Thyroid hormone stimulates acetyl-CoA carboxylase- $\alpha$ transcription in hepatocytes by modulating the composition of nuclear receptor complexes bound to a thyroid hormone response element. J. Biol. Chem. 2001, 276, 974-983. [CrossRef] [PubMed]

68. Kawai, K.; Sasaki, S.; Morita, H.; Ito, T.; Suzuki, S.; Misawa, H.; Nakamura, H. Unliganded thyroid hormone receptor- $\beta 1$ represses liver $X$ receptor $\alpha$ /oxysterol-dependent transactivation. Endocrinology 2004, 145, 5515-5524. [CrossRef] [PubMed]

69. Blennemann, B.; Leahy, P.; Kim, T.S.; Freake, H.C. Tissue-specific regulation of lipogenic mRNAs by thyroid hormone. Mol. Cell Endocrinol. 1995, 110, 1-8. [CrossRef]

70. Yin, L.; Zhang, Y.; Hillgartner, F.B. Sterol regulatory element-binding protein-1 interacts with the nuclear thyroid hormone receptor to enhance acetyl-CoA carboxylase- $\alpha$ transcription in hepatocytes. J. Biol. Chem. 2002, 277, 19554-19565. [CrossRef] [PubMed]

71. Stapleton, S.R.; Mitchell, D.A.; Salati, L.M.; Goodridge, A.G. Triiodothyronine stimulates transcription of the fatty acid synthase gene in chick embryo hepatocytes in culture. Insulin and insulin-like growth factor amplify that effect. J. Biol. Chem. 1990, 265, 18442-18446. [PubMed] 
72. Magaña, M.M.; Osborne, T.F. Two tandem binding sites for sterol regulatory element binding proteins are required for sterol regulation of fatty-acid synthase promoter. J. Biol. Chem. 1996, 271, 32689-32694. [CrossRef] [PubMed]

73. Lopez, J.M.; Bennett, M.K.; Sanchez, H.B.; Rosenfeld, J.M.; Osborne, T.F. Sterol regulation of acetyl coenzyme A carboxylase: A mechanism for coordinate control of cellular lipid. Proc. Natl. Acad. Sci. USA 1996, 93, 1049-1053. [CrossRef] [PubMed]

74. Hashimoto, K.; Yamada, M.; Matsumoto, S.; Monden, T.; Satoh, T.; Mori, M. Mouse sterol response element binding protein-1c gene expression is negatively regulated by thyroid hormone. Endocrinology 2006, 147, 4292-4302. [CrossRef] [PubMed]

75. Cable, E.E.; Finn, P.D.; Stebbins, J.W.; Hou, J.; Ito, B.R.; van Poelje, P.D.; Linemeyer, D.L.; Erion, M.D. Reduction of hepatic steatosis in rats and mice after treatment with a liver-targeted thyroid hormone receptor agonist. Hepatology 2009, 49, 407-417. [CrossRef] [PubMed]

76. Swierczynski, J.; Mitchell, D.A.; Reinhold, D.S.; Salati, L.M.; Stapleton, S.R.; Klautky, S.A.; Struve, A.E.; Goodridge, A.G. Triiodothyronine-induced accumulations of malic enzyme, fatty acid synthase, acetyl-coenzyme A carboxylase, and their mRNAs are blocked by protein kinase inhibitors. Transcription is the affected step. J. Biol. Chem. 1991, 266, 17459-17466. [PubMed]

77. Hashimoto, K.; Ishida, E.; Matsumoto, S.; Okada, S.; Yamada, M.; Satoh, T.; Monden, T.; Mori, M. Carbohydrate response element binding protein gene expression is positively regulated by thyroid hormone. Endocrinology 2009, 150, 3417-3424. [CrossRef] [PubMed]

78. Gauthier, K.; Billon, C.; Bissler, M.; Beylot, M.; Lobaccaro, J.M.; Vanacker, J.M.; Samarut, J. Thyroid hormone receptor $\beta(\mathrm{TR} \beta)$ and liver $X$ receptor (LXR) regulate carbohydrate-response element-binding protein (ChREBP) expression in a tissue-selective manner. J. Biol. Chem. 2010, 285, 28156-28163. [CrossRef] [PubMed]

79. Paradies, G.; Ruggiero, F.M. Effect of hyperthyroidism on the transport of pyruvate in rat-heart mitochondria. Biochim. Biophys. Acta 1988, 935, 79-86. [CrossRef]

80. Paradies, G.; Ruggiero, F.M. Enhanced activity of the tricarboxylate carrier and modification of lipids in hepatic mitochondria from hyperthyroid rats. Arch. Biochem. Biophys. 1990, 278, 425-430. [CrossRef]

81. Vaulont, S.; Munnich, A.; Decaux, J.F.; Kahn, A. Transcriptional and post-transcriptional regulation of L-type pyruvate kinase gene expression in rat liver. J. Biol. Chem. 1986, 261, 7621-7625. [PubMed]

82. Spence, J.T.; Pitot, H.C.; Zalitis, G. Regulation of ATP-citrate lyase in primary cultures of adult rat hepatocytes. J. Biol. Chem. 1979, 254, 12169-12173. [PubMed]

83. González-Manchón, C.; Butta, N.; Ferrer, M.; Ayuso, M.S.; Parrilla, R. Molecular cloning and functional characterization of the human cytosolic malic enzyme promoter: Thyroid hormone responsiveness. DNA Cell Biol. 1997, 16, 533-544. [CrossRef] [PubMed]

84. González-Manchón, C.; Ayuso, M.S.; Parrilla, R. AP-1 and T3RE cis elements operate as a functional unit in the transcriptional control of the human malic enzyme gene. Gene 1999, 226, 111-119. [CrossRef]

85. Fritz, S.R.; Kletzien, R.F. Regulation of glucose-6-phosphate dehydrogenase by diet and thyroid hormones. Mol. Cell Endocrinol. 1987, 51, 13-17. [CrossRef]

86. Thompson, K.S.; Towle, H.C. Localization of the carbohydrate response element of the rat L-type pyruvate kinase gene. J. Biol. Chem. 1991, 266, 8679-8682. [PubMed]

87. Davis, P.J.; Davis, F.B. Nongenomic actions of thyroid hormone. Thyroid 1996, 6, 497-504. [CrossRef] [PubMed]

88. Brown, S.B.; Maloney, M.; Kinlaw, W.B. "Spot 14" protein functions at the pretranslational level in the regulation of hepatic metabolism by thyroid hormone and glucose. J. Biol. Chem. 1997, 272, 2163-2166. [PubMed]

89. Gharbi-Chihi, J.; Facchinetti, T.; Bergé-Lefranc, J.L.; Bonne, J.; Torresani, J. Triiodothyronine control of ATP-citrate lyase and malic enzyme during differentiation of a murine preadipocyte cell line. Horm. Metab. Res. 1991, 23, 423-427. [CrossRef] [PubMed]

90. Moon, Y.A.; Lee, J.J.; Park, S.W.; Ahn, Y.H.; Kim, K.S. The roles of sterol regulatory element-binding proteins in the transactivation of the rat ATP citrate-lyase promoter. J. Biol. Chem. 2000, 275, 30280-30286. [CrossRef] [PubMed] 
91. Fang, X.; Hillgartner, F.B. Alterations in retinoid X receptor- $\alpha$ expression contribute to cell-type dependent differences in thyroid hormone regulation of malic enzyme transcription. Mol. Cell. Endocrinol. 2000, 164, 41-52. [CrossRef]

92. Towle, H.C.; Mariash, C.N.; Oppenheimer, J.H. Changes in the hepatic levels of messenger ribonucleic acid for malic enzyme during induction by thyroid hormone or diet. Biochemistry 1980, 19, 579-585. [CrossRef] [PubMed]

93. Shimomura, I.; Shimano, H.; Korn, B.S.; Bashmakov, Y.; Horton, J.D. Nuclear sterol regulatory element-binding proteins activate genes responsible for the entire program of unsaturated fatty acid biosynthesis in transgenic mouse liver. J. Biol. Chem. 1998, 273, 35299-35306. [CrossRef] [PubMed]

94. Czyzewska, U.; Tylicki, A.; Siemieniuk, M.; Strumilo, S. Changes of activity and kinetics of certain liver and heart enzymes of hypothyroid and $\mathrm{T}_{3}$-treated rats. J. Physiol. Biochem. 2012, 68, 345-351. [CrossRef] [PubMed]

95. Miksicek, R.J.; Towle, H.C. Changes in the rates of synthesis and messenger RNA levels of hepatic glucose-6-phosphate and 6-phosphogluconate dehydrogenases following induction by diet or thyroid hormone. J. Biol. Chem. 1982, 257, 11829-11835. [PubMed]

96. Mariash, C.N.; Seelig, S.; Schwartz, H.L.; Oppenheimer, J.H. Rapid synergistic interaction between thyroid hormone and carbohydrate on mRNA S14 induction. J. Biol. Chem. 1986, 261, 9583-9586. [PubMed]

97. Zhu, Q.; Anderson, G.W.; Mucha, G.T.; Parks, E.J.; Metkowski, J.K.; Mariash, C.N. The Spot 14 protein is required for de novo lipid synthesis in the lactating mammary gland. Endocrinology 2005, 146, 3343-3350. [CrossRef] [PubMed]

98. Mater, M.K.; Thelen, A.P.; Pan, D.A.; Jump, D.B. Sterol response element-binding protein 1c (SREBP1c) is involved in the polyunsaturated fatty acid suppression of hepatic S14 gene transcription. J. Biol. Chem. 1999, 274, 32725-32732. [CrossRef] [PubMed]

99. Ma, L.; Tsatsos, N.G.; Towle, H.C. Direct role of ChREBP.Mlx in regulating hepatic glucose-responsive genes. J. Biol. Chem. 2005, 280, 12019-12027. [CrossRef] [PubMed]

100. Keyes, W.G.; Wilcox, H.G.; Heimberg, M. Formation of the very low density lipoprotein and metabolism of $\left[1-{ }^{14} \mathrm{C}\right]$-oleate by perfused livers from rats treated with triiodothyronine or propylthiouracil. Metabolism 1987, 30, 135-146. [CrossRef]

101. Prieur, X.; Huby, T.; Coste, H.; Schaap, F.G.; Chapman, M.J.; Rodríguez, J.C. Thyroid hormone regulates the hypotriglyceridemic gene APOA5. J. Biol. Chem. 2005, 280, 27533-27543. [CrossRef] [PubMed]

102. Laker, M.E.; Mayes, P.A. Effect of hyperthyroidism and hypothyroidism on lipid and carbohydrate metabolism of the perfused rat liver. Biochem. J. 1981, 196, 247-255. [CrossRef] [PubMed]

103. Al-Tonsi, A.A.; Abdel-Gayoum, A.A.; Saadm, M. The secondary dyslipidemia and deranged serum phosphate concentration in thyroid disorders. Exp. Mol. Pathol. 2004, 76, 182-187. [CrossRef] [PubMed]

104. De Lange, P.; Cioffi, F.; Senese, R.; Moreno, M.; Lombardi, A.; Silvestri, E.; de Matteis, R.; Lionetti, L.; Mollica, M.P.; Goglia, F.; Lanni, A. Nonthyrotoxic prevention of diet-induced insulin resistance by 3,5-diiodo-L-thyronine in rats. Diabetes 2011, 60, 2730-2739. [CrossRef] [PubMed]

105. Grasselli, E.; Voci, A.; Demori, I.; Canesi, L.; de Matteis, R.; Goglia, F.; Lanni, A.; Gallo, G.; Vergani, L. 3,5-Diiodo-L-thyronine modulates the expression of genes of lipid metabolism in a rat model of fatty liver. J. Endocrinol. 2012, 212, 149-158. [CrossRef] [PubMed]

106. Grasselli, E.; Voci, A.; Canesi, L.; Salis, A.; Damonte, G.; Compalati, A.D.; Goglia, F.; Gallo, G.; Vergani, L. 3,5-Diiodo-L-thyronine modifies the lipid droplet composition in a model of hepatosteatosis. Cell. Physiol. Biochem. 2014, 33, 344-356. [CrossRef] [PubMed]

107. Mendoza, A.; Navarrete-Ramírez, P.; Hernández-Puga, G.; Villalobos, P.; Holzer, G.; Renaud, J. P.; Laudet, V.; Orozco, A. 3,5-T2 is an alternative ligand for the thyroid hormone receptor $\beta 1$. Endocrinology 2013, 154, 2948-2958. [CrossRef] [PubMed]

108. Senese, R.; Lasala, P.; Leanza, C.; de Lange, P. New avenues for regulation of lipid metabolism by thyroid hormones and analogs. Front. Physiol. 2014, 5, 475. [CrossRef] [PubMed]

109. Ruderman, N.B.; Carling, D.; Prentki, M.; Cacicedo, J.M. AMPK, insulin resistance, and the metabolic syndrome. J. Clin. Investig. 2013, 123, 2764-2772. [CrossRef] [PubMed]

110. Hardie, D.G.; Ross, F.A.; Hawley, S.A. AMPK: A nutrient and energy sensor that maintains energy homeostasis. Nat. Rev. Mol. Cell Biol. 2012, 13, 251-262. [CrossRef] [PubMed] 
111. Saggerson, D. Malonyl-CoA, a key signaling molecule in mammalian cells. Annu. Rev. Nutr. 2008, 28, 253-272. [CrossRef] [PubMed]

112. Ruderman, N.B.; Xu, X.J.; Nelsonm, L.; Cacicedo, J.M.; Saha, A.K.; Lan, F.; Ido, Y. AMPK and SIRT1: A long-standing partnership? Am. J. Physiol. Endocrinol. Metab. 2010, 298, E751-E760. [CrossRef] [PubMed]

113. Jonas, W.; Lietzow, J.; Wohlgemuth, F.; Hoefig, C.S.; Wiedmer, P.; Schweizer, U.; Köhrle, J.; Schürmann, A. 3,5-Diiodo-L-thyronine (3,5-t2) exerts thyromimetic effects on hypothalamus-pituitary-thyroid axis, body composition, and energy metabolism in male diet-induced obese mice. Endocrinology 2015, 156, 389-399. [CrossRef] [PubMed]

114. Rochira, A.; Damiano, F.; Marsigliante, S.; Gnoni, G.V.; Siculella, L. 3,5-Diiodo-L-thyronine induces SREBP-1 proteolytic cleavage block and apoptosis in human hepatoma (HepG2) cells. Biochim. Biophys. Acta 2013, 1831, 1679-1689. [CrossRef] [PubMed]

115. Antonelli, A.; Fallahi, P.; Ferrari, S.M.; di Domenicantonio, A.; Moreno, M.; Lanni, A.; Goglia, F. 3,5-Diiodo-L-thyronine increases resting metabolic rate and reduces body weight without undesirable side effects. J. Biol. Regul. Homeost. Agents 2011, 25, 655-660. [PubMed]

116. Flavin, R.; Peluso, S.; Nguyen, P.L.; Loda, M. Fatty acid synthase as a potential therapeutic target in cancer. Future Oncol. 2010, 6, 551-562. [CrossRef] [PubMed]

117. Menendez, J.A.; Lupu, R. Fatty acid synthase and the lipogenic phenotype in cancer pathogenesis. Nat. Rev. Cancer 2007, 7, 763-777. [CrossRef] [PubMed]

(C) 2017 by the authors. Licensee MDPI, Basel, Switzerland. This article is an open access article distributed under the terms and conditions of the Creative Commons Attribution (CC BY) license (http:/ / creativecommons.org/licenses/by/4.0/). 